\title{
Optimization of fibrinase productivity from Actinomycetes
}

\author{
Habib S. A. ${ }^{1}$, Abo doubara M. I. ${ }^{2}$, Abdel-Malak Camelia. A. ${ }^{1}$, and Badawy Rasha. \\ M. ${ }^{1}$ \\ 1- Chemistry Department (Biochemistry Division), Faculty of Science (Damietta), \\ Mansoura University, Egypt. \\ 2- Botany Department, Faculty of Science (Damietta), Mansoura University, Egypt.
}

\begin{abstract}
Background: Fibrinolytic enzymes that dissolve blood clots and show promise for thrombosis therapy have been successfully identified from various sources. A wide range of microorganisms has been screened for their fibrinolytic properties. A fibrinolytic protease has been isolated from Streptomyces violaceoruber and Streptomyces spiroverticillatus culture filtrate.

Methods : The purification procedure involved ammonium sulphate fractionation, dialysis, calcium phosphate gel purification and gel filtration on Sephadex G-100. By using native polyacrylamide gel electrophoresis (Native PAGE) to determine molecular weight of the enzyme.

Results : The optimum temperature for the high production of fibrinase from S. violaceoruber was $30^{\circ} \mathrm{C}$ and from $S$. spiroverticillatus was $35^{\circ} \mathrm{C}$ and the optimum $\mathrm{pH}$ was 9.0. The best incubation period is 6 days. The incorporation of lactose as carbon source, yeast extract as nitrogen source and $\mathrm{MnCl}_{2}$ to culture media highly increased the production of fibrinase from the two species. The molecular weight was about $30 \mathrm{KDa}$.
\end{abstract}

Conclusion: It exhibited fibrinolytic enzyme activity. In vitro studies revealed that fibrinase dissolves clots made by blood.

Key words: Fibrinase, Fibrinolytic enzyme, streptomyces, fibrin clots

\section{Introduction}

Hemostasis is a complex process obtained through an optimal balance between bleeding and blood clot formation. In an unbalanced state, fibrin clots may not be lysed resulting in thrombosis (Pandee et al., 2008). Thrombolytic agents from various sources have been extensively investigated. Enzymes, such as urokinase, streptokinase and tissues plasminogen activators have been widely used in the treatment of thrombosis. However, these enzymes are often expensive, thermolabile and can produce undesirable side effects (Chitte and Dey, 2000).

Fibrinolytic enzymes that dissolve blood clots and show promise for thrombosis therapy have been successfully identified from various sources. A wide range of microorganisms has been screened for their fibrinolytic properties (Takeno et al., 1999). Fibrinase is defined as a fibrin stabilizing plasma enzyme (Transglutaminases) that is activated by Thrombin and calcium to form Factor XIIIA. It is important for stabilizing the formation of the fibrin polymer (clot) which culminates the coagulation cascade. Organisms producing fibrinolytic enzymes as Bacteria (Agrebi et al., 2009), Fungi (Bin et al., 2009), Plants (Kostanova et al., 2005), Parasites (Motoyashiki et al., 2003), Snakes (Girón et al., 2008), Nattokinase (Gordon 2005), Cloning of earthworm and Escherichia coli (Li ., 2007), cloning of Escherichia coli and Pichia pastoris (Yang 
et al., (2008) and Actinomycetes( $\underline{\text { Bono }}$ et al., 1996).

Actinomycetes are considered as save source for fibrinolytic enzymes. So, this work aimed at production and characterization of protein with fibrinolytic activity from Actinomycetes and investigation of its effect on human blood clot.

\section{Materials and methods}

Two mesophilic Actinomycetes, $S$. violaceoruber and $S$. spiroverticillatus succeed to grow on selective media.

Pure stock cultures were maintained on starch-nitrate agar slants in a refrigerator at $4{ }^{\circ} \mathrm{C}$. Sub-culturing of vegetative mycelium was carried out monthly.

2.1. Starch-nitrate agar for growth and maintenance: (Waksman, 1959)

It composed of starch $(20.0 \mathrm{~g}), \mathrm{KNO}_{3}$ $\left(\begin{array}{llll}2.0 & \mathrm{~g}\end{array}\right), \quad \mathrm{K}_{2} \mathrm{HPO}_{4} \quad(1.0 \mathrm{~g}), \quad \mathrm{MgSO}_{4} .7 \mathrm{H}_{2} \mathrm{O}$ $(0.5 \mathrm{~g}), \quad \mathrm{NaCl} \quad(0.5 \mathrm{~g}), \quad \mathrm{CaCO}_{3} \quad(3.0 \mathrm{~g})$, $\mathrm{FeSO}_{4} .7 \mathrm{H}_{2} \mathrm{O}(0.01 \mathrm{~g})$, agar $(20.0 \mathrm{~g})$ and distilled water $(1000 \mathrm{ml}), \mathrm{pH} 7.2-7.4$.

2.2. Media used for the production of fibrinase:

It composed of bovine fibrin $(2.0 \mathrm{~g})$, $\mathrm{KH}_{2} \mathrm{PO}_{4}(0.001 \mathrm{~g}), \mathrm{NH}_{4} \mathrm{NO}_{3}(0.05 \mathrm{~g})$, $\left(\mathrm{NH}_{4}\right)_{2} \mathrm{SO}_{4}(0.5 \mathrm{~g})$ and trace salt solution (1 ml) complete volume to $1000 \mathrm{ml}$ with distilled water.

\subsection{Trace salt solution:-}

It composed of $\mathrm{ZnCl}_{2}(0.001 \mathrm{~g})$, $\mathrm{MnSo}_{4}(0.0005 \mathrm{~g}), \mathrm{CuCl}_{2}(0.0008 \mathrm{~g})$, $\left(\mathrm{NH}_{2}\right)_{2} \mathrm{SO}_{4}(0.001 \mathrm{~g}), \mathrm{CaCl}_{2}(0.0001 \mathrm{~g})$ and boric acid $(0.001 \mathrm{~g})$ dissolved in 1000 distilled water.

\subsection{Preparation of crude fibrinase:}

The Actinomycetes were grown in 250 conical flasks each contain $50 \mathrm{ml}$ liquid media. The flasks were incubated at optimum conditions for enzyme production for time intervals (2-4-6-8) days.

At the expiry of the experiment, the culture was filtered and the supernatant was used as the source of the enzyme.

\subsection{Assay of fibrinolytic enzyme:}

The assay of the fibrinolytic enzyme activity was carried out according to the modified method of Basha and Beevers (1975). The reaction mixture contained 1 $\mathrm{ml}$ of bovine fibrin $(2 \mathrm{~g} / \mathrm{l})$ as a substrate suspended in $0.2 \mathrm{M}$ phosphate buffer $(\mathrm{pH}$ 7.0 ) and $0.25 \mathrm{ml}$ of fibrinase preparation, was incubated for $60 \mathrm{~min}$ at $40{ }^{\circ} \mathrm{C}$. The reaction was stopped by adding $0.1 \mathrm{ml}$ trichloroaceticacid (T.C.A) followed by centrifugation at $2000 \mathrm{rpm}$ for $15 \mathrm{~min}$. The peptides released were measured using the method of Lowry et al. (1951). Absorbance was read at $750 \mathrm{~nm}$ and bovine albumin was used as a standard. One unit of fibrinase was defined as the amount of enzyme that produces, in $1 \mathrm{hr}, 1 \mathrm{mg}$ of soluble peptides as a product of fibrin hydrolysis (El-Shora et al., 2002).

\subsection{Determination of protein}

The protein content was measured colorimetrically using a method of Lowry et al. (1951).

2.7. Optimization of the fibrinase production of Streptomyces violaceoruber and Streptomyces spiroverticillatus.

2.7.1. The optimum incubation time was evaluated by varying sampling times $(2,4$, 6 and 8 days). The influence of different values of $\mathrm{pH}(5,6,7,8,9$ and 10) and molarity were studied. The effect of temperature was determined by incubating under different temperatures $(25,30,35$ and $\left.40{ }^{\circ} \mathrm{C}\right)$.

2.7.2. Effect of incorporation of different carbon sources into fibrin media

Several mono-, di- and polysaccharides were used as carbon sources in the media in addition to fibrin to study their effects on the fibrinase productivity and growth. Glucose, galactose, fructose, lactose, sucrose and starch were tested for their effect of incorporation in fibrinase media.

2.7.3. Effect of incorporation of different trace elements into fibrin media

The effect of trace elements such as $\mathrm{FeCl}_{2}, \mathrm{ZnCl}_{2}, \mathrm{MnCl}_{2}, \mathrm{CoCl}_{2}, \mathrm{NiCl}_{2}, \mathrm{CuCl}_{2}$, $\mathrm{CdCl}_{2}$, EDTA, $\mathrm{MgCl}_{2}, \mathrm{KCl}, \mathrm{CaCl}_{2}, \mathrm{HgCl}_{2}$ and $\mathrm{NaCl}$ on fibrinase productivity of $S$. violaceoruber and $S$. spiroverticillatus with a comparison to control culture media that contain trace salt solution [It composed of $\mathrm{ZnCl}_{2}, \mathrm{MnSO}_{4}, \mathrm{CuCl}_{2},\left(\mathrm{NH}_{4}\right)_{2} \mathrm{SO}_{4}, \mathrm{CaCl}_{2}$ and boric acid]. 
2.7.4. Effect of incorporation of different Nitrogen sources into fibrin media

Several nitrogen sources were used in the media to study their effects on the fibrinase productivity. Nitrogen sources that have been used were yeast extract, beef extract, peptone and casein.

\subsection{Polyacrylamide Gel Electrophoresis} Electrophoresis

\section{Results}

\subsection{Effect of incubation period}

The results showed that, the optimum incubation period for the high fibrinase production from both $S$. violaceoruber and $S$. spiroverticillatus was after 6 days of incubation (figure.1).

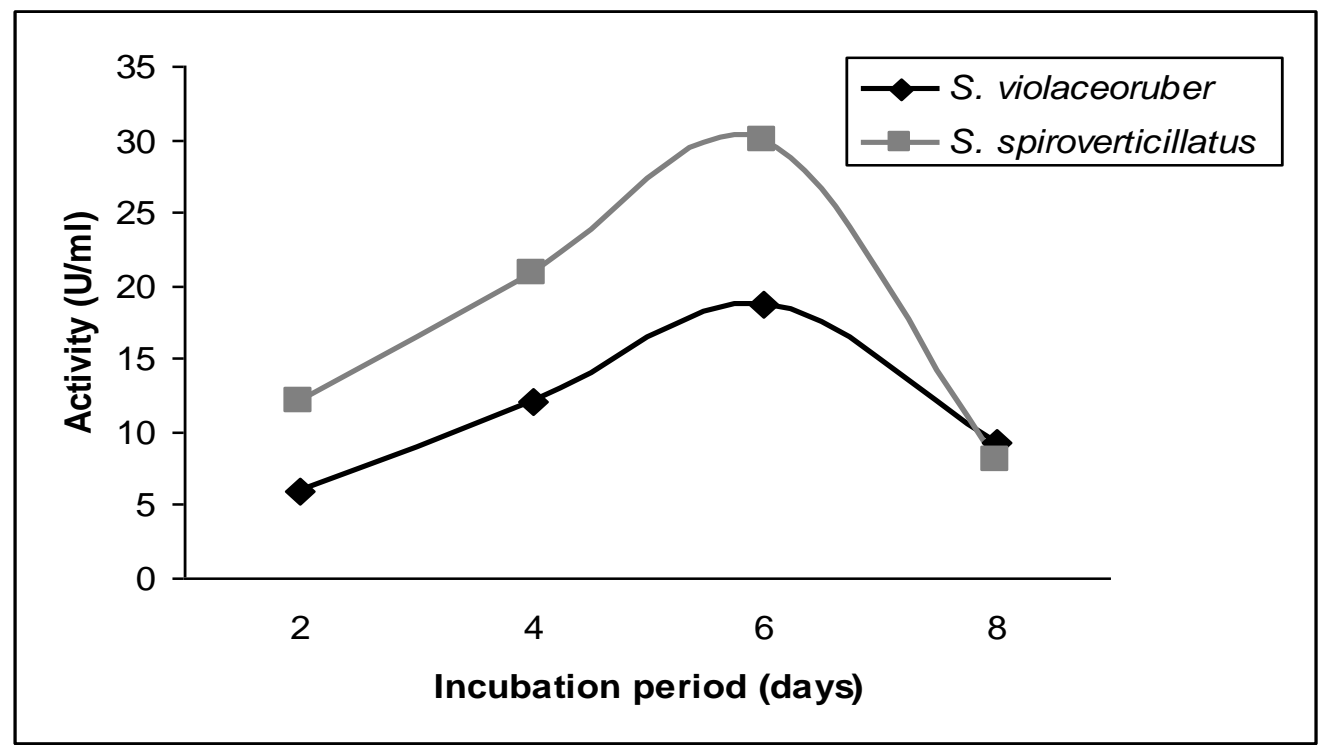

(Figure 1) Effect of incubation period on fibrinase productivity from $S$. violaceoruber and $S$. spiroverticillatus

\begin{abstract}
Native proteases were electrophoretically separated using the method of Keith and John, (1994) and dissociation proteins (SDS- PAGE) were separated by using the method of Laemmli (1970). The separated proteins on the polyacrylamide gel of both methods were stained with Coomassie blue R-250 (Andrews, 1986).
\end{abstract}




\section{2-Effect of temperature}

The optimum temperature for the high production of fibrinase from $S$. violaceoruber was $30^{\circ} \mathrm{C}$ and from S. spiroverticillatus was $35^{\circ} \mathrm{C}$ (Figures 2 and 3).

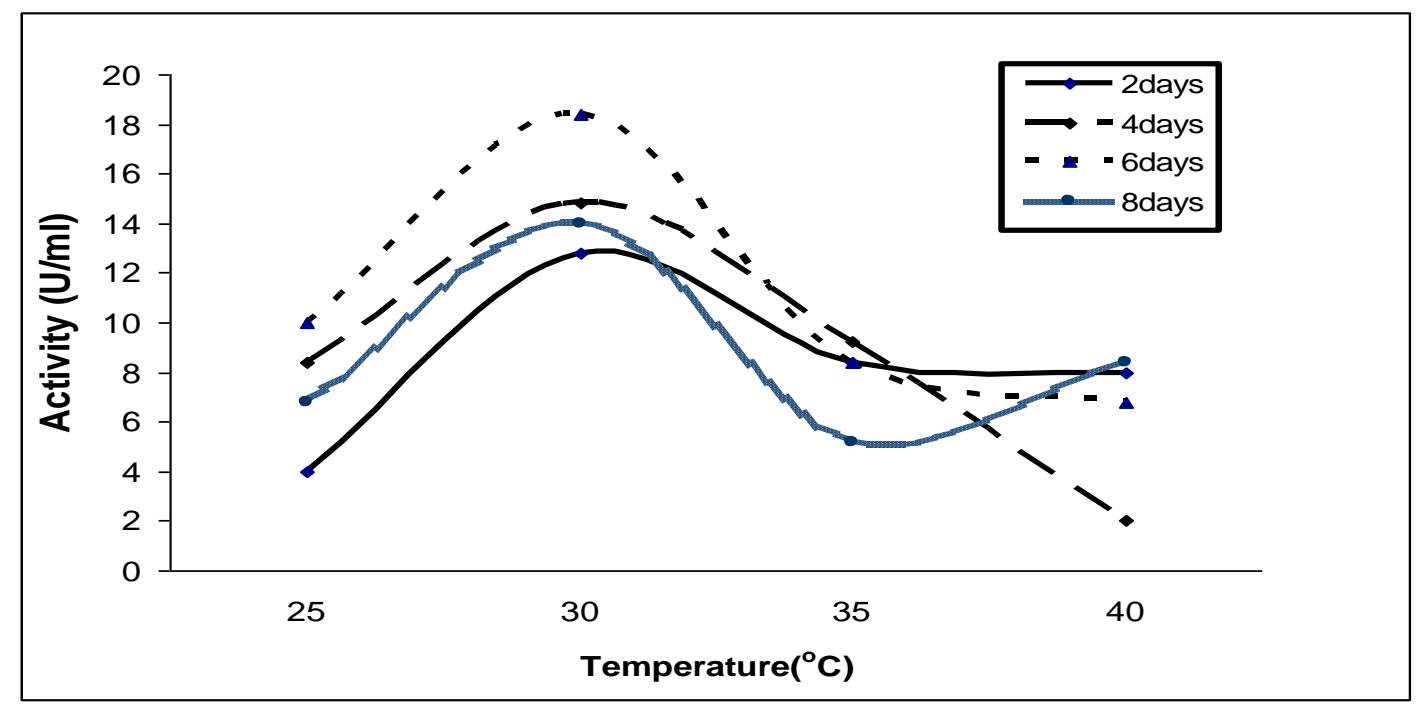

Figure 2: Effect of temperature on fibrinase production from $S$. violaceoruber at different incubation periods.

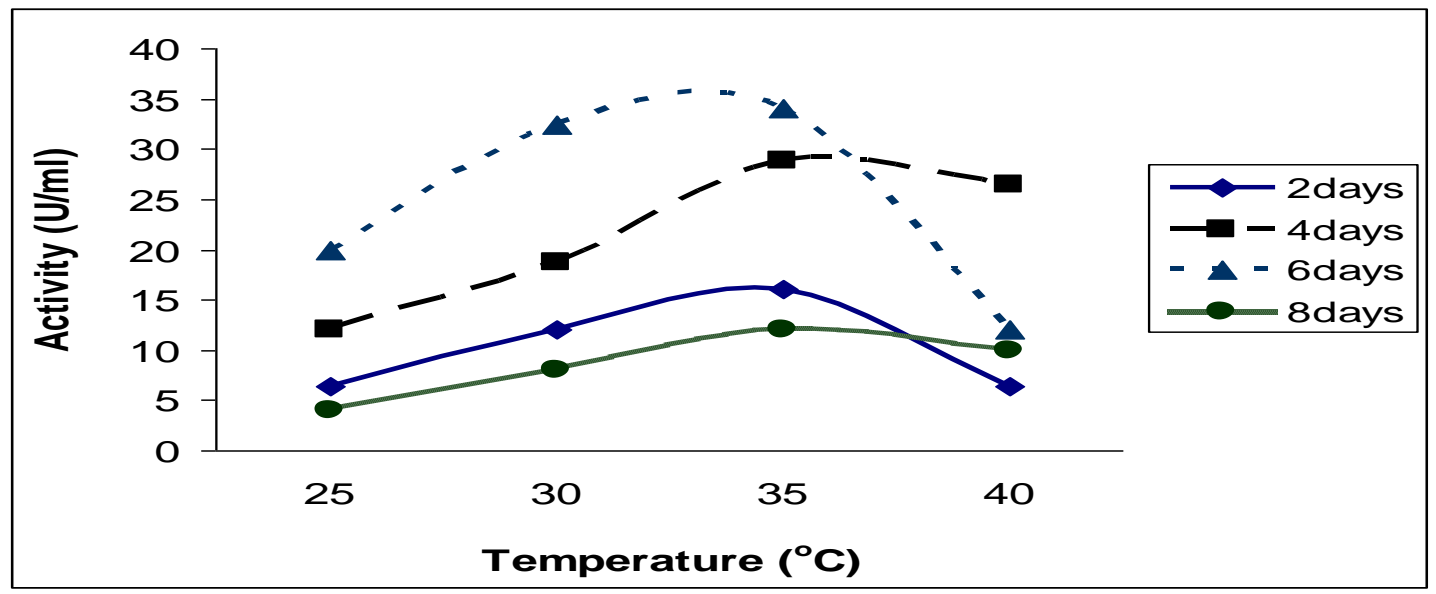

Figure 3: Effect of temperature on fibrinase production from $S$. spiroverticillatus at different incubation periods. 
Optimization of....

\subsection{Effect of initial pH of fibrin media}

The $\mathrm{pH}$ values of 6 and 9 were the best for fibrinase activity in S. violaceoruber (Figure 4) and the $\mathrm{pH}$ values of 7 and 9 were the best for fibrinase activity in $S$. spiroverticillatus (Figure 5).

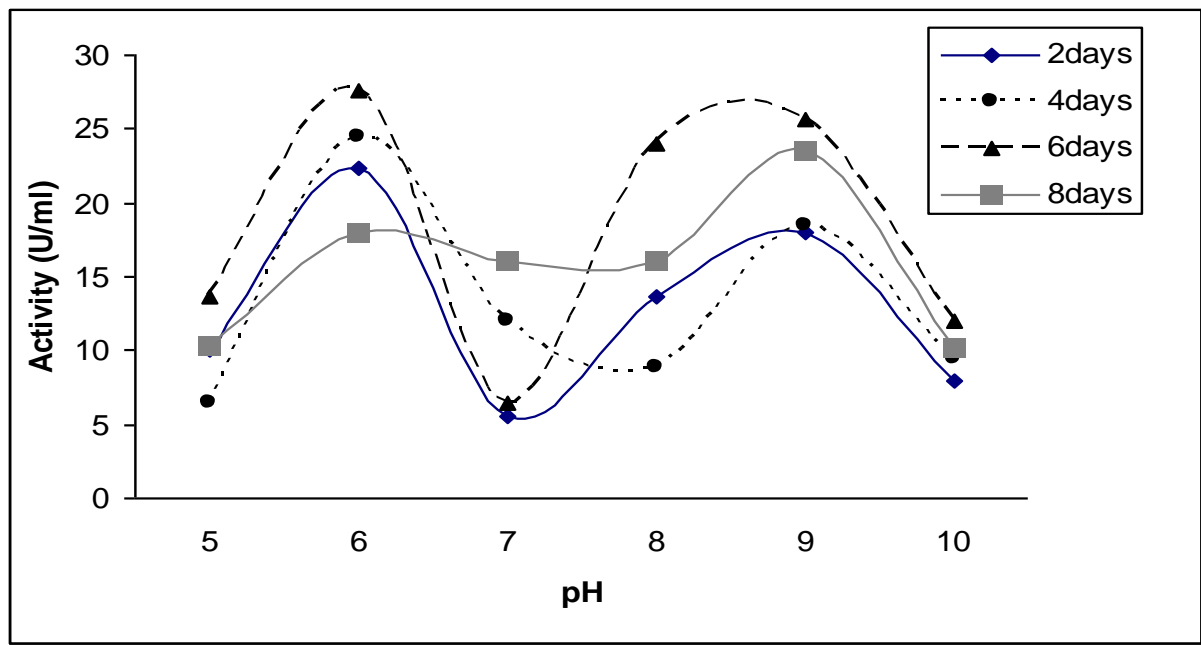

Figure 4: Effect of culture pH on fibrinase production from $S$. violaceoruber at different incubation periods.

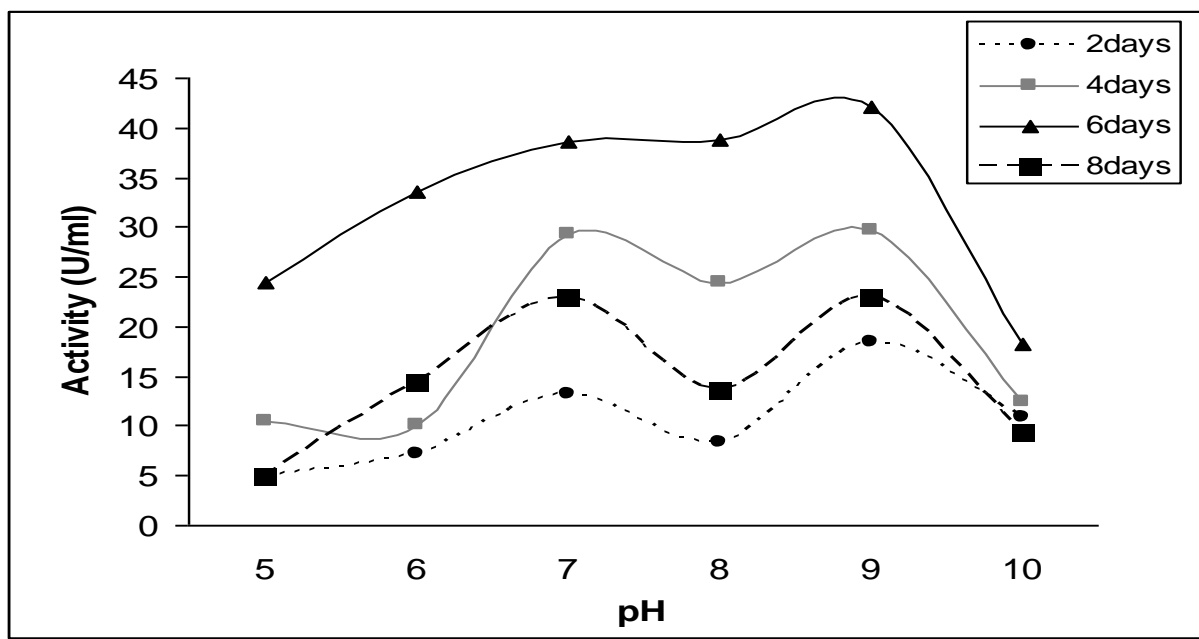

Figure 5: Effect of culture pH on fibrinase productivity from $S$. spiroverticillatus 3.4. Effect of molarity of the buffering system

The optimal fibrinase production from $S$. violaceoruber was at a concentration $0.05 \mathrm{M}$ of $\mathrm{K}_{2} \mathrm{HPO}_{4}$ ( $\mathrm{pH}$ 7.0) after 6-days period (Figure 6). However, the maximum production of fibrinase from S. spiroverticillatus was at $0.1 \mathrm{M}$ of phosphate buffer (Figure 7). 


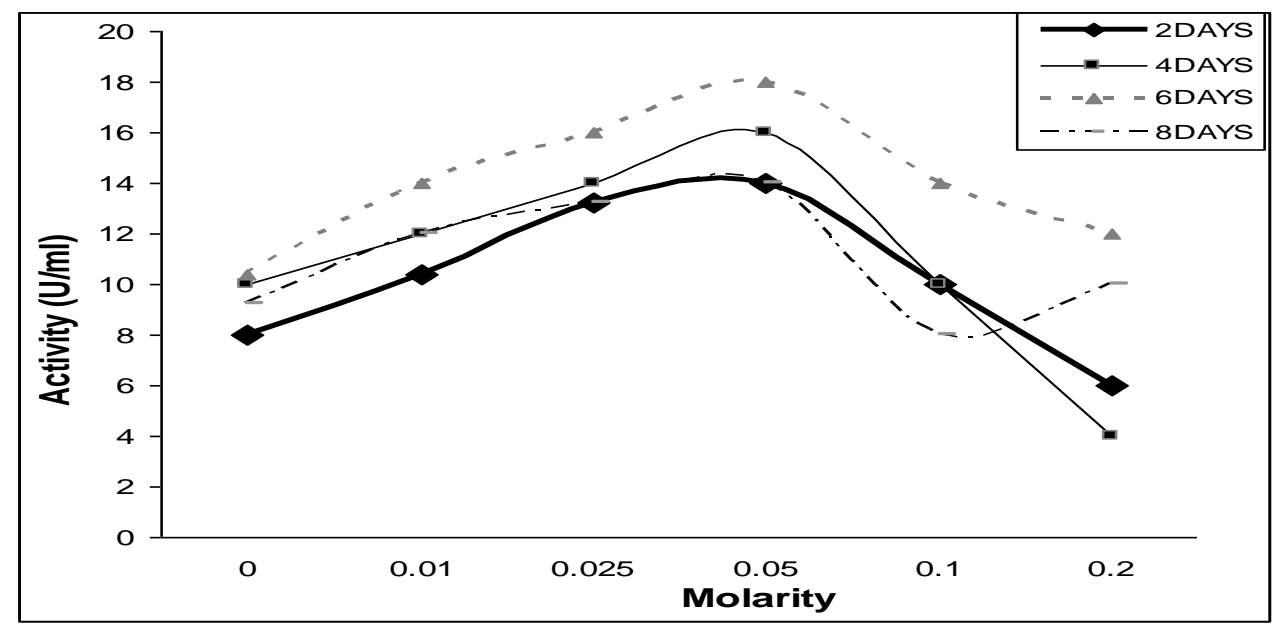

Figure 6: Effect of the molarity of the buffering system of the culture media on fibrinase production from $S$. violaceoruber at different incubation periods

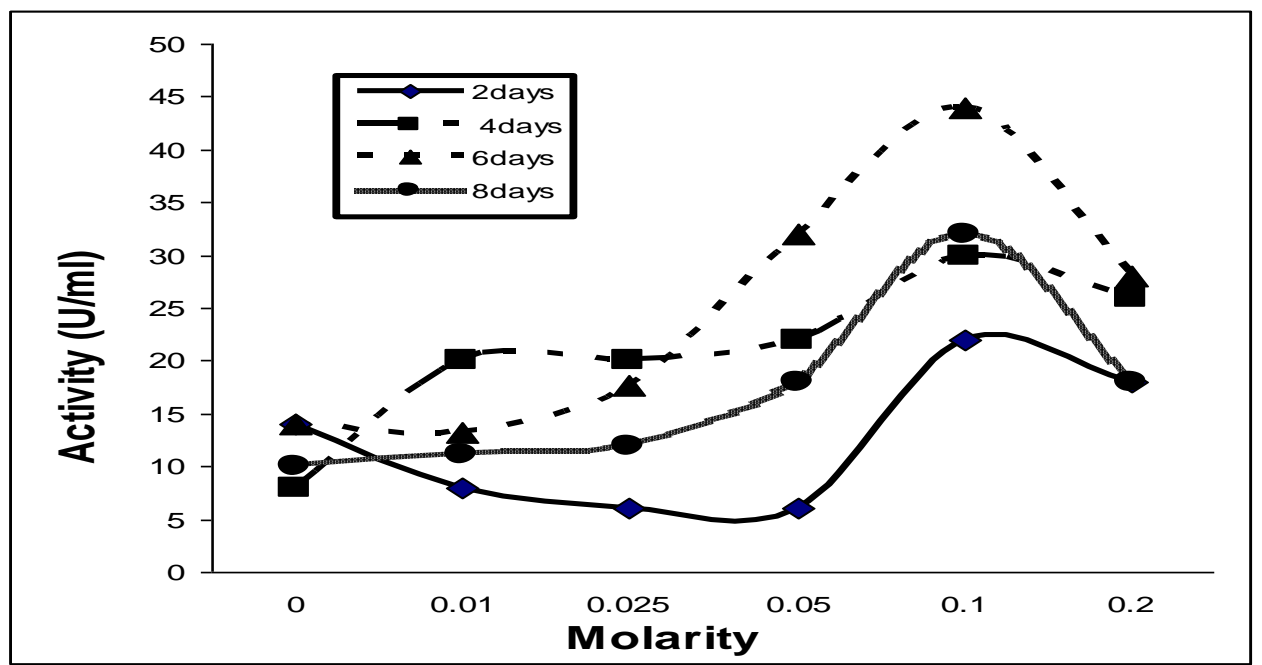

Figure 7: Effect of the molarity of the buffering system of the culture media on fibrinase production from $S$. spiroverticillatus at different incubation periods 
.5. Effect of incorporation of different carbon sources into fibrin media

The highest production of fibrinase from $S$. violaceoruber was achieved after 6-days in media supplemented with lactose (Figure 8), and the maximum production of fibrinase from $S$. spiroverticillatus was achieved after 6-days in media supplemented with starch (Figure 9).

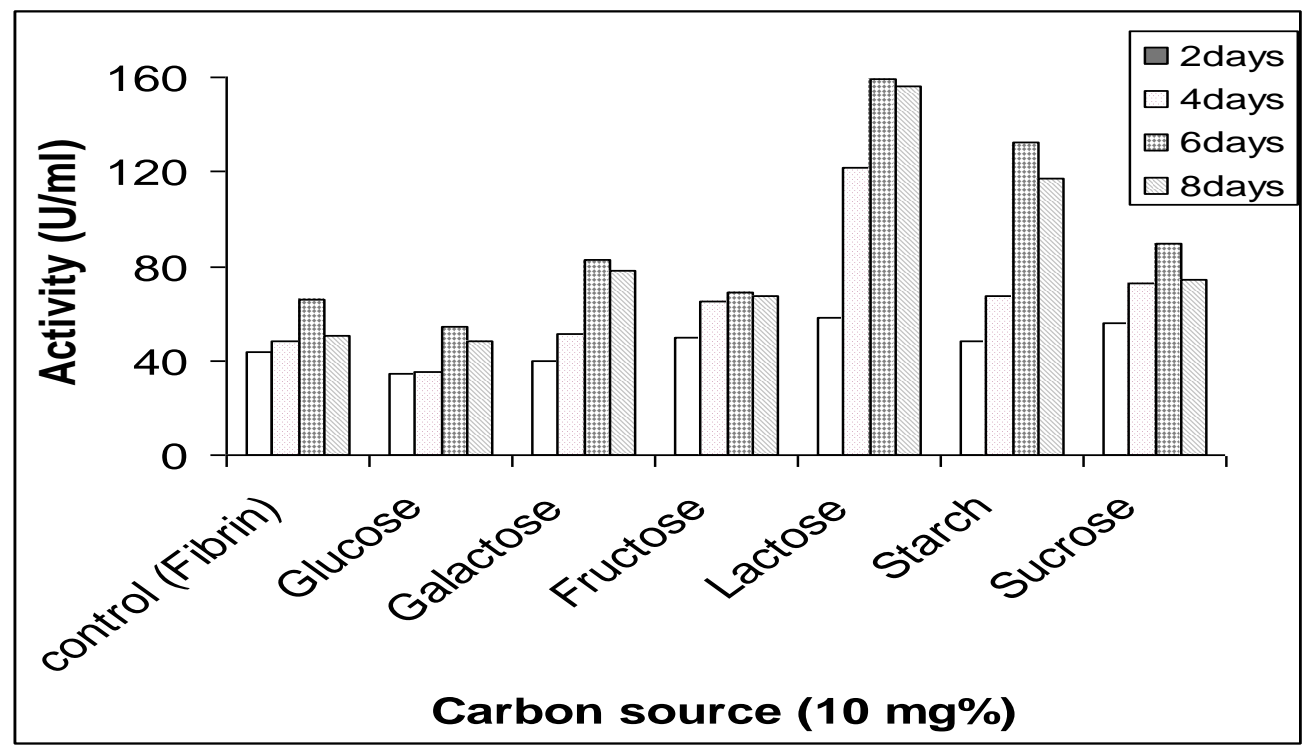

Figure 8: Effect of incorporation of different carbon sources into fibrin media on fibrinase production from $S$. violaceoruber at various durations.

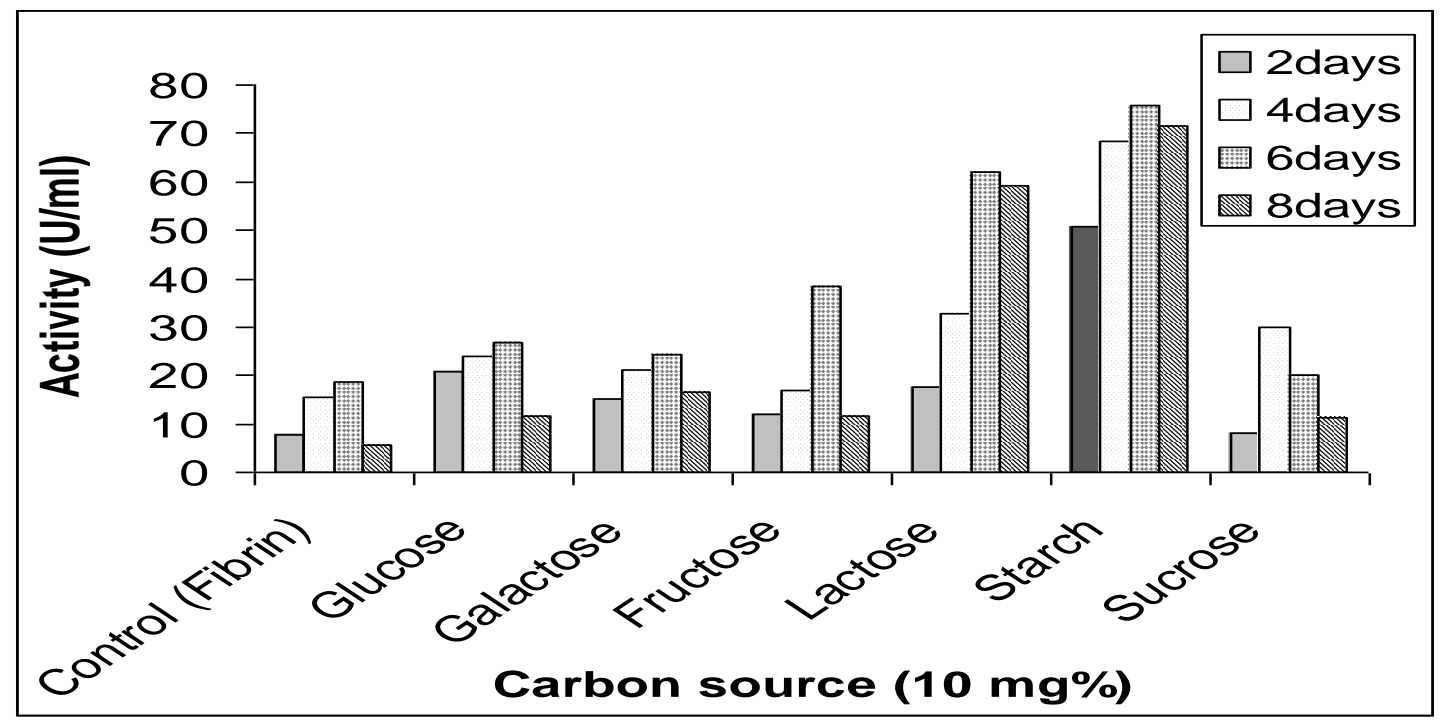

Figure 9: Effect of incorporation of different carbon sources into fibrin media on fibrinase production from $S$. spiroverticillatus at various durations 


\subsection{Effect of incorporation of different trace elements into fibrin media}

Figures 10 and 11 show the effect of trace elements as $\mathrm{FeCl}_{2}, \mathrm{ZnCl}_{2}, \mathrm{MnCl}_{2}, \mathrm{CoCl}_{2}$, $\mathrm{NiCl}_{2}, \mathrm{CuCl}_{2}$, EDTA, $\mathrm{MgCl}_{2}, \mathrm{KCl}, \mathrm{CaCl}_{2}, \mathrm{HgCl}_{2}$ and $\mathrm{NaCl}$ on fibrinase productivity of $S$. violaceoruber and $S$. spiroverticillatus, with a comparison to control culture media that contain trace salt solution. All metals were added in concentration $0.1 \mathrm{mg} \%$. The maximum yield of enzyme was achieved at 4-days at $\mathrm{MnCl}_{2}$ then declined with age.

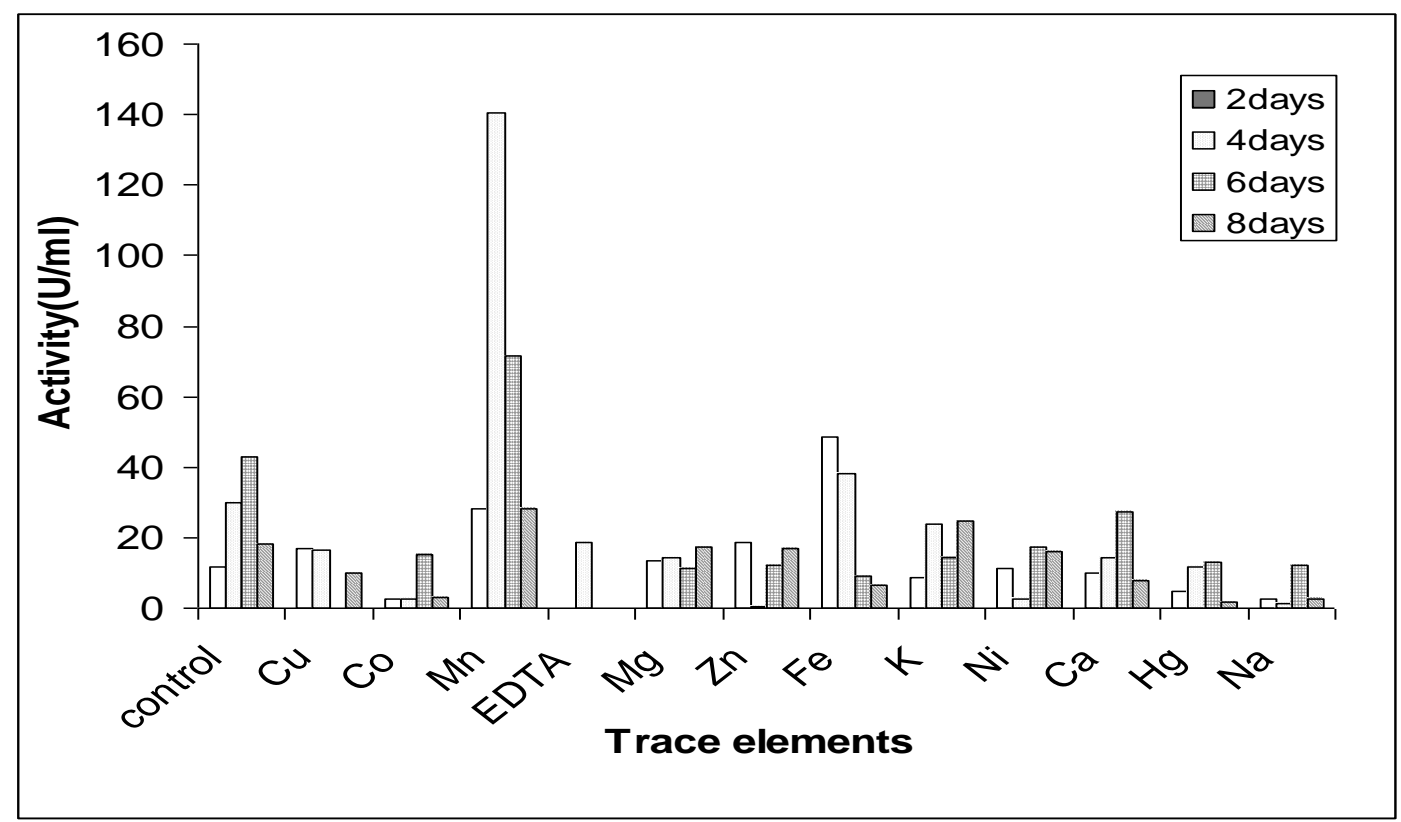

Fig.10: Effect of incorporation of different trace elements and EDTA into culture media on fibrinase productivity from $S$. violaceoruber at different incubation period

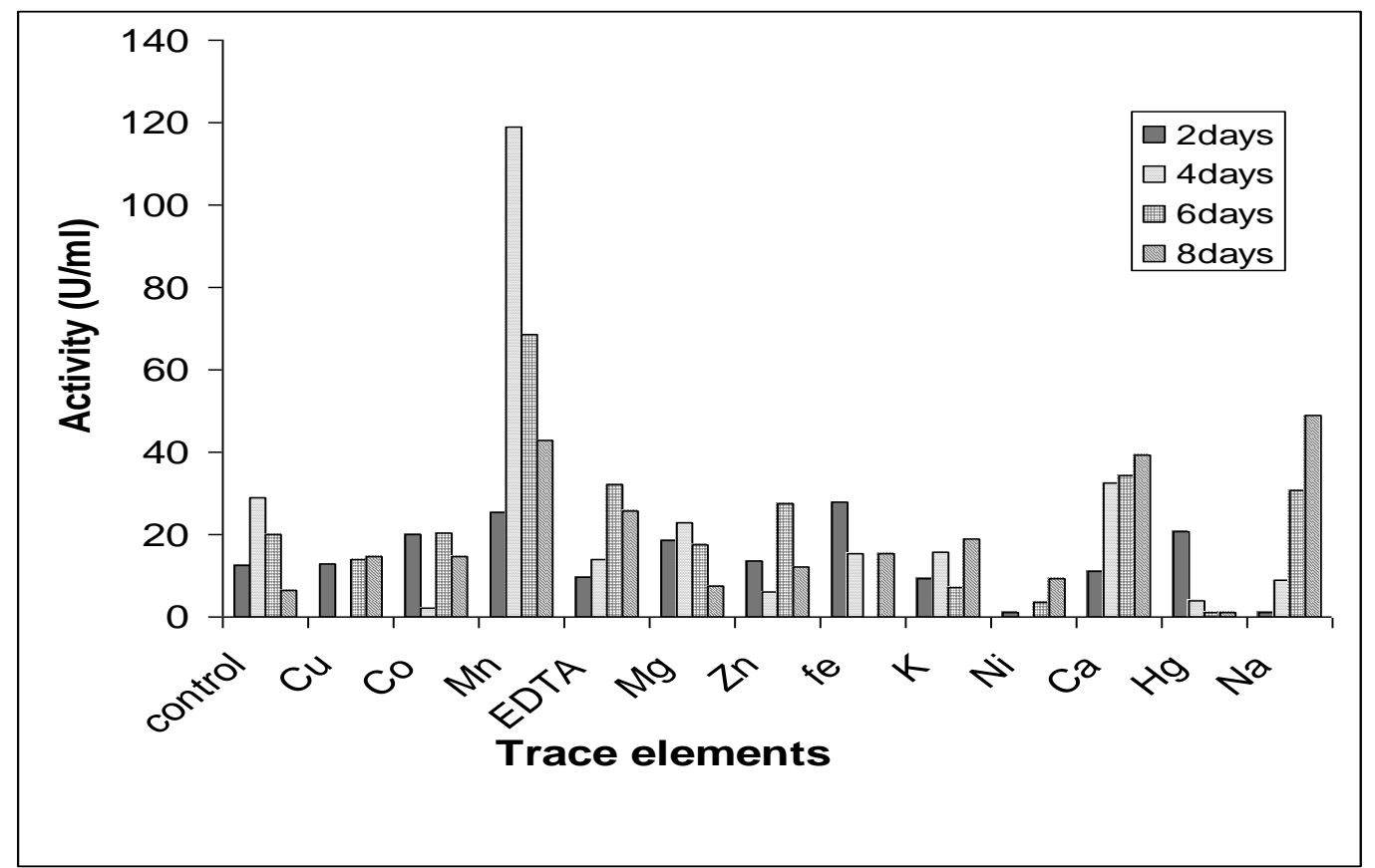

Fig.11: Effect of incorporation of different trace elements and EDTA into culture media on fibrinase productivity from S.spiroverticillatus at different 


\subsection{Effect of incorporation of different Nitrogen sources into fibrin media}

Yeast extract gives highly increased in fibrinase production in both Streptomycetes in $S$. violaceoruber, the production increased after 4-days but in S. spiroverticillatus, the production increased at 6-days. Beef extract and peptone slightly increased the production of fibrinase from the two species.

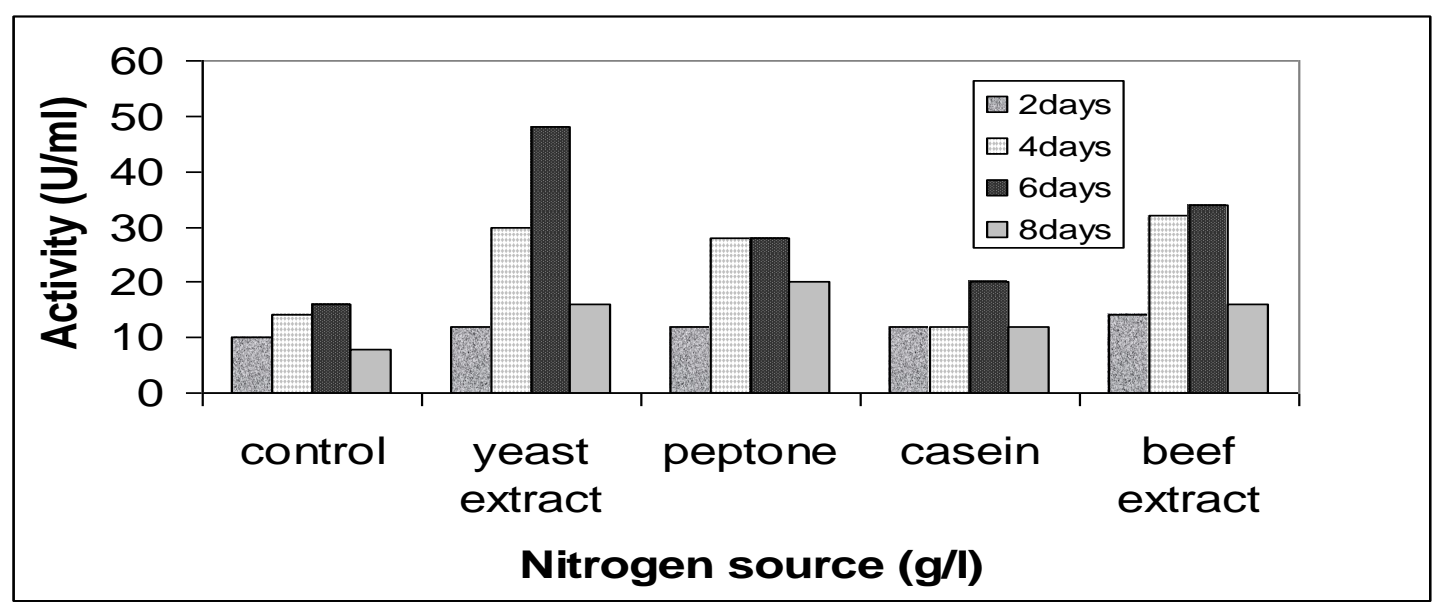

Figure 12: Effect of incorporation of different nitrogen sources into media on fibrinase productivity from $S$. violaceoruber at various durations

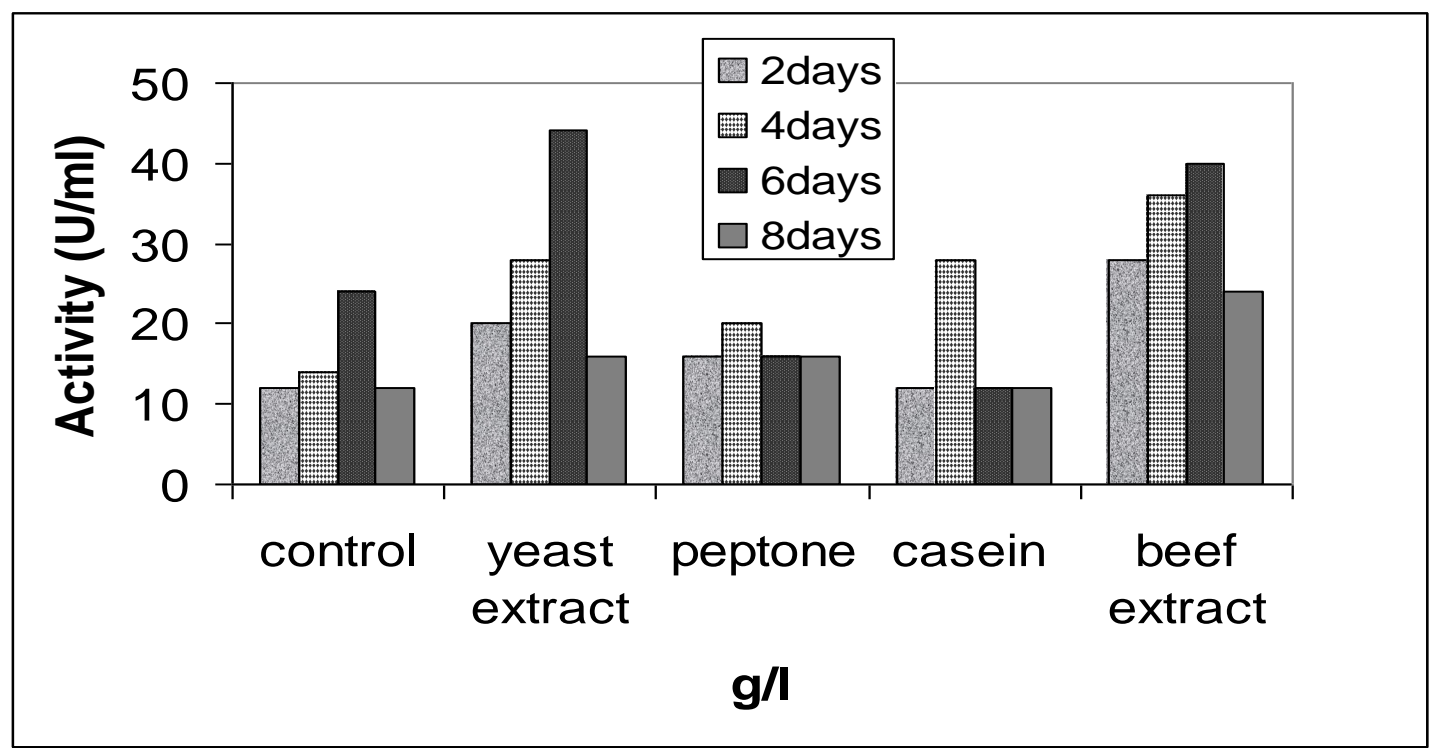

Figure 13: Effect of incorporation of different nitrogen sources into media on fibrinase productivity from $S$. spiroverticillatus at various durations. 


\subsection{Estimation of molecular weight of fibrinase:}

The protein solutions from different purification steps of S. violaceoruber and $S$. spiroverticillatus were analyzed by polyacrylamide-PAGE without SDS to determine the molecular weight of native fibrinase and with SDS to determine the molecular weight of the fibrinase (Figures 14 and 15). Fibrinase from $S$. violaceoruber and $S$. spiroverticillatus has molecular weight of $30 \mathrm{KDa}$ with single protein band.

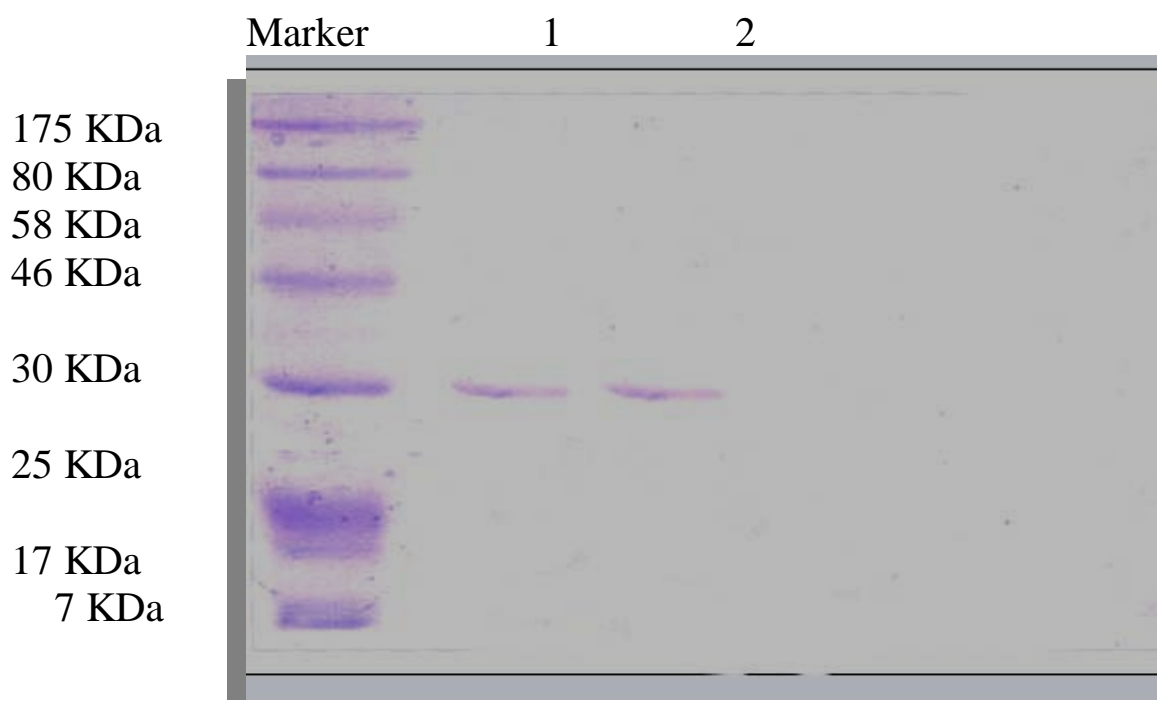

Figure 14: Native PAGE for the purified fibrinase after sephadex G-100 purification step of $S$. violaceoruber (lane1) and $S$. spiroverticillatus (lane 2) using prestained broad range protein marker.

Molecular weight marker includes: Maltose-binding protein- $\beta$-galactoside (MBP- $\beta$-galactoside) (175 KDa), MBP-paramyosin (80 KDa), MBP-chitin binding domain (MBP-CBD) (58 KDa), CBD-Mxe Intein-2CBD (46 KDa), CBD-Mxe Intein (30 KDa), CBD-BmFKBP13 (25 KDa), Lysozyme (17 KDa), and Aprotinin (7 KDa).

Lane 1: contain purified fibrinase after sephadex G-100 step of S. violaceoruber.

Lane 2: contain purified fibrinase after sephadex G-100 step of S. spiroverticillatus

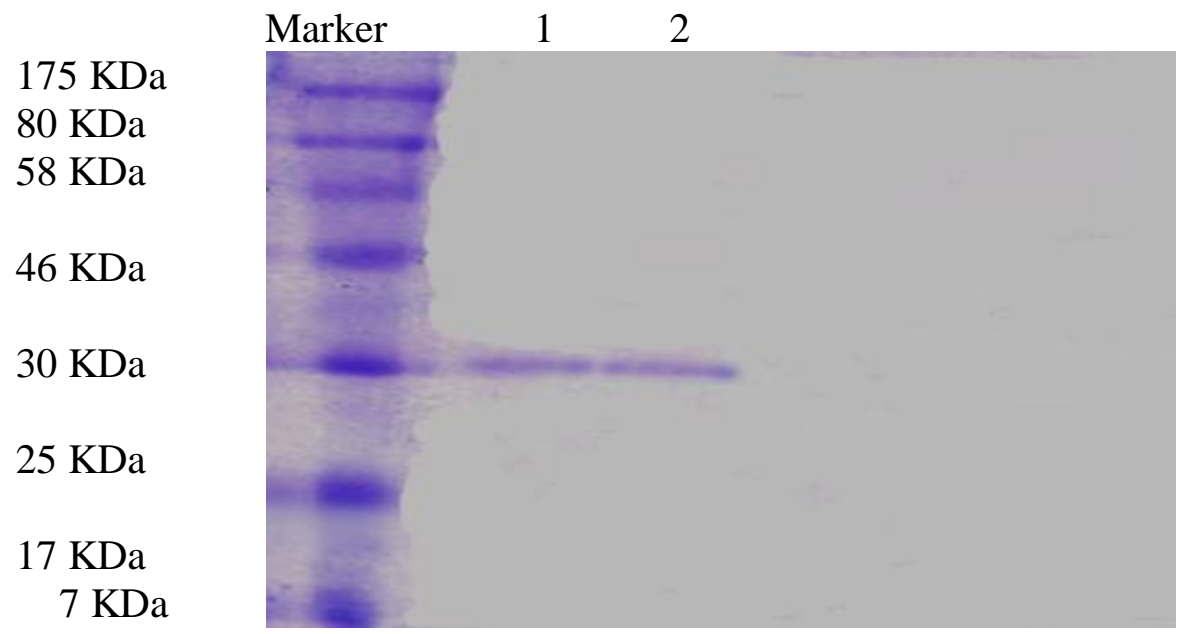

Figure 15: SDS- PAGE for the purified fibrinase after sephadex G.100 purification step of S. violaceoruber (lane 1) and S. spiroverticillatus (lane 2) using prestained broad range protein marker. 
Molecular weight marker as in figure 14

Lane 1: contain purified fibrinase after sephadex G-100 step of S. violaceoruber.

Lane 2: contain purified fibrinase after sephadex G-100 step of $S$. spiroverticillatus.

\subsection{Effect of fibrinase on human blood clot:}

The effect of the purified fibrinase from $S$. spiroverticillatus was tested on human blood clot. After incubation the produced free proteins and polypeptides from human blood clot were applied onto PAGE. It was observed that lysis of human blood clot by fibrinase from $S$. spiroverticillatus was complete at $180 \mathrm{~min}$ (Figure 16).

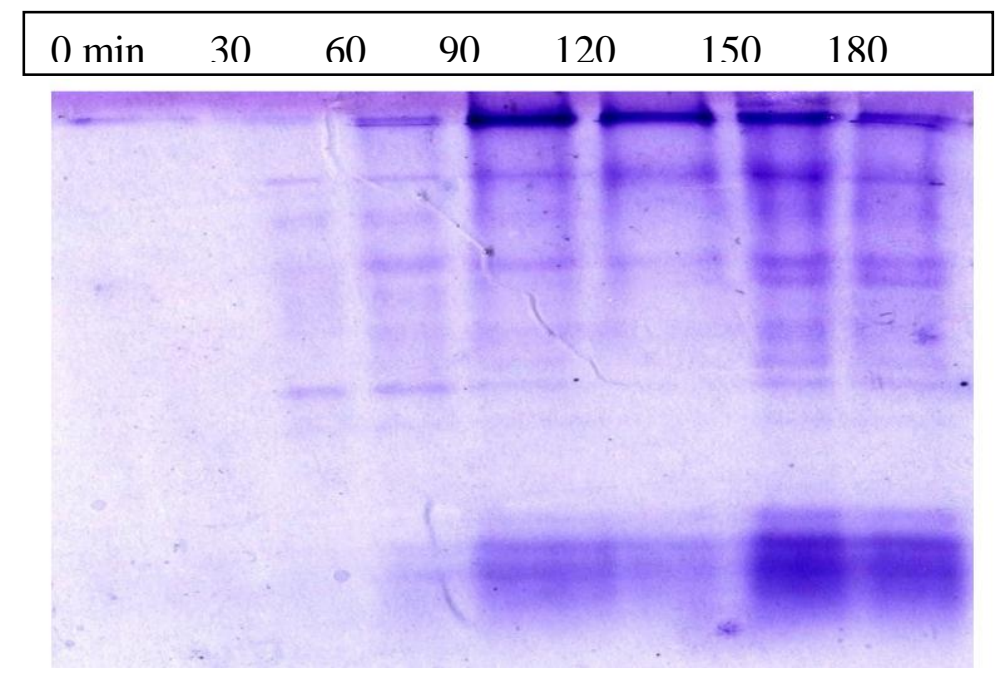

Figure 16: Native PAGE for the effect of fibrinase from S. spiroverticillatus on human blood clot at various time intervals (0-180 min) of incubation.

\section{Discussion:}

Actinomycetes as any
microorganism have a powerful
intracellular defense mechanism to keep
their life, thus, it can be expected that they
have a highly fibrinolytic productivity; also
Actinomycetes are safe source for research
studies, because they are not toxic and not
pathogenic microorganisms.

The optimal productivity of fibrinase from $S$. violaceoruber and $S$. spiroverticillatus was after 6 days of incubation, where the optimum productivity of enzyme was reported at $\mathrm{pH} 9.0$ and at temperature $30{ }^{\circ} \mathrm{C}$ and $35{ }^{\circ} \mathrm{C}$ for $\boldsymbol{S}$. violaceoruber and $S$. spiroverticillatus, respectively. The maximum enzyme productivity was at buffer molarity 0.05 mol for $\boldsymbol{S}$. violaceoruber and $0.1 \mathrm{~mol}$ for $\boldsymbol{S}$. spiroverticillatus. This coincided with the productivity of other enzymes from other sources also affected by the molarity of the buffering system (El-Waseef $\boldsymbol{e t}$ al., 1993). All sugars decrease enzyme productivity, except lactose and starch increased enzyme productivity from $S$. violaceoruber and $S$. spiroverticillatus, respectively. Previously, in this concept, galactose increased asparaginase and protease produtivity from A. niger, while asparaginase productivity from $A$. terreus was stimulated by starch, fructose, glucose, galactose, cellulose and sucrose (El-Waseef et al., 1993).

Trace elements exhibited significant effect on the production of fibrinase. Administration of trace elements to the culture media of $S$. violaceoruber and $S$. spiroverticillatus highly reduced the production of the enzyme, except $\mathrm{MnCl}_{2}$, which highly increased the production of 
fibrinase from the two species. Previously, Foda et al. (1980) reported that $\mathrm{CaCl}_{2}$ stimulated the production of asparaginase from $W p$. Polymorpha, while $\mathrm{ZnSO}_{4}$, $\mathrm{FeSO}_{4}, \mathrm{CuSO}_{4}$ and $\mathrm{MgSO}_{4}$ caused slight decreased in the production, also Allison and Macfariane (1992) found that $\mathrm{Ca}^{2+}$, $\mathrm{Mn}$ and $\mathrm{Co}^{2+}$ stimulated the activity of protease from Clostridium sporogenes. Also El-Waseef et al. (1993) reported that $\mathrm{Co}^{2+}, \mathrm{Ni}^{2+}, \mathrm{Zn}^{2+}$ and $\mathrm{Cu}^{2+}$ increased asparaginase productivity from $\mathrm{A}$. terreus.

The present study showed that the molecular weight of fibrinase native from both $S$. violaceoruber and $S$. spiroverticillatus was approximately 30.0 $\mathrm{KDa}$ and, composed of a single band on SDS-PAGE. These results agree with fibrinase purified from Bacillus amyloliquefaciens An6 which have molecular weight $30 \mathrm{kDa}$ by sodium dodecyl sulfate polyacrylamide gel electrophoresis (Agrebi et al., 2010). Previously, Kim et al. (1996) reported that fibrinolytic enzyme purified from Bacillus sp.strainCK11-4 molecular weight was 28.2 $\mathrm{KDa}$ as determined by sodium dodecyl sulfate-polyacrylamide gel electrophoresis.

The fibrinase from $S$. spiroverticillatus showed a great affinity towards human blood clot compared to bovine albumin. These results are in accordance with the findings of El-Shora et al. (2002), Abdelfattah et al. (1993) and El-Nagar et al. (1997).

\section{References}

1. Abdel-Fattah AF, Ismail AS and Salah SA (1993): Purification and properties of two fibrinolytic enzymes from Fusarium oxysporum NRC(1). Zentralb-Mikrobiol., 148: 123- 128.

2. Agrebi R, Hmidet N, Hajji M, Ktari N, Haddar A, Fakhfakh-Zouari $\mathbf{N}$ and Nasri $M$ (2010): Fibrinolytic serine protease isolation from Bacillus amyloliquefaciens An6 grown on Mirabilis jalapa tuber powders. Appl Biochem Biotechnol., 162(1): 75-88.

3. Agrebi R, Haddar A, Hajji M, Frikha F, Manni L, Jellouli $K$ and Nasri M (2009): Fibrinolytic enzymes from a newly isolated marine bacterium Bacillus subtilis A26: characterization and statistical media optimization. Can J Microbiol., 55(9):1049-61. 4. Allision C and Macfariane GT (1992): Physiological and nutritional determinants of protease secretion by Clostridium sporogenes. Characterization of six extracellular proteases. Appl. Microbial Biotechnol., 37 (2): 152-156.

5. Andrews A.T. (1986): Electrophoresis: theory techniques and biochemical and clinical application. $2^{\text {nd }}$ ed. Oxford University Press New York : 213-242.

6. Basha SMM and Beevers L (1975): The development of proteolytic activity and protein degradation during the germination of Pisum sativum. Planta, 124: 77-80.

7. Bin $W$, Licheng $W$, Chen W, Yang $Z$ and Luo M (2009): Purification and characterization of a novel fibrinolytic protease from Fusarium sp. CPCC 480097 Journal of Industrial Microbiology and Biotechnology., 36(3), 451-459

8. Bono F, Savi P, Tuong A, Maftouh M, Pereillo JM, Capdevielle J, Guillemot JC, Maffrand JP and Herbert JM (1996): Purification and characterization of a novel protease from culture filtrates of a Streptomyces sp. FEMS Microbiol Lett.., 141(2-3): 213-20.

9. Chitte RR and Dey S (2000): Potent fibrinolytic enzyme from a thermophilic Streptomyces megasporus strain SD 5. Letters in Applied Microbiology., 31: 405-410

10. El-Nagar MM, Habib SA and AbdelFattah GM (1997): Characterization of a fibrinolytic enzyme from Penicillium decumbans. Bull. Fac. Sci. Mansoura Univ. Egypt., 24(1): 187-197.

11. El-Shora HM, Habib SA, Metwally A and Darwish BD (2002): Fibrinolytic activity from bacilli. The Egyptian Journal of Biochemistry \& Molecular biology, 20(2): 81.

12. El-Waseef AM, El-Sharabasy MM, Ashour SA and Habib SA (1993): Biochemical Studies on the Utilization of Whey by Microorganisms. Ph. D.

13. Foda MS, Zedan HH and Hashem SA (1980): Formation of L-glutaminase and Lasparaginase activities in Pichia polymorpha. Acta Microbiol. Pol., 29 (4): 343-352.

14. Girón ME, Salazar AM, Aguilar I, Pérez JC, Sánchez EE, Arocha-Piñango CL, Rodríguez-Acosta A and Guerrero B (2008): Comparative Biochemistry and Physiology Part C: Toxicology \& Pharmacology, 147(1) 113121

15. Gordon G (2005): Aspirin vs. Enzymes. The Doctor's Prescription for Healthy Living. Virtual Laf Conference., 2(3): 3-9. 
16. Keith W. and John W. (1994): Principles and techniques. In : Practical Biochemistry. Published Cambridge University; 425.

17. Kim W, Choi KH, Kim YH, Park HH, Choi JY, Lee YS, Kwon I and Lee SS (1996): Purification and Characterization of a Fibrinolytic Enzyme Produced from Bacillus sp.strain CK11-4 Screened from Chung kook Jang Applied and Environmental Microbiology, 62: 2482-2488

18. Kostanova EA, Rozenfeld MA, Revina TA and Valueva TA (2007): Protein inhibitors of fibrin stabilizing factor FXIII. Izv Akad Nauk Ser Biol., 3: 283-289.

19. Li D, Tong $W$ and Yang $Y$ (2007):

Functional expression of an earthworm fibrinolytic enzyme in Escherichia coli World Journal of Microbiology and Biotechnology, 24(5): 613-618.

20. Lowry OH, Rosebrough NJ, Farr AL and Ranadall RJ (1951): Protein measurement with the Folin-phenol reagent. J. Biol. Chem., 193: 265-275

21. Motoyashiki T, Anthony T, Azimov DA and Ibragim $K$ (2003): Isolation of anticoagulant from the venom of tick, Boophilus calcaratus, from Uzbekistan. Thrombosis Research, 110 (4): 235-241

22. Pandee P, Kittikul Ak, Ohsugi, Masahiro and Dissara Y (2008): Production and properties of a fibrinolytic enzyme by Schizophyllum commune BL23 Songklanakarin J. Sci. Technol, 30 (4): 447-453.

23. Takeno T, Okamura T, Sera M, Takana M, Fukuda $S$ and Ohsugi $M$ (1999): Screening of fibrinolytic enzymes of microorganisms. The Bulletin of Muko-gawa's University Natural of Science, 47: 67-72.

24. Waksman SA (1959): Strain specificity and production of antibiotics $\mathrm{X}$. Characterization and classification of species within the streptomycetes griseus group. Proc. Natl. Acad. Sci. U. S., 45: 1043-1047.

25. Yang L, Dong W, Jinchao H, Xiubao R and Yan W (2008): Expression and Purification of Natural N-Terminal Recombinant Bovine Pancreatic Trypsin Inhibitor from Pichia pastoris; Biol. Pharm. Bull., 31(9): 16801685 . 


\section{اللإنتاجية المثلى لانزيم الفيبرينيز من الأكتينوميسيتات}

سالم عبد الهادى حبيب1 ، محمد اسماعيل ابو دبارة2 , كاميليا عادلى عبد الملاك1 , رشا بدوى1.

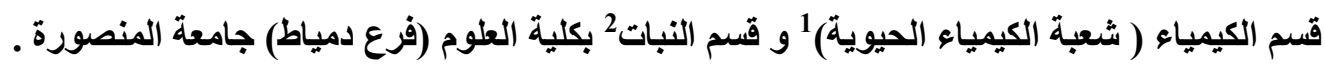

انزيم الفيبرينيز له دور كبير داخل أجسام الكائنات الحيه فهو يعتبرانزيم يحلل بروتين الفيبرين ـ الفيبرين هو الناتج

النهائى للجلطة الدموية ولذلك فعدة أبحاث قامت لتحسين العو امل المذيبة للجلطة وخاصة من الكائنات الدقيقة.

تعيين الظروف البيئية المنلى لانتاج انزيم الفيبرينيزمن استربتو ميسيس فيو لاسيوروبر و واستربتو ميسيس

اسبيروفيرتيسيلاتس.

و وامتدت الدر اسة لتعين الظروف البيئية المثلى لانتاج انزيم الفيبرينيز وذلك لكلا النوعين من الأستربتوميسيس وقد دلت النتائج على أن الظروف المثلى لانتاج الانزيم لكل من الكائنين كالآتى:

\section{• • - مترة التحضين 6 أيام. \\ • • - الرقم الهيدروجينى هو 9.}

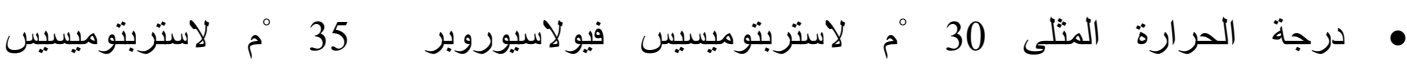

$$
\text { اسبيروفيرنيسيلاتس. }
$$

• مادة اللاكتوز هى أحسن مصدر كربونى لانتاج الفيبرينيز من استربتوميسيس فيو لاسيوروبر و مادتين

اللاكتوزو النشا هما أحسن مصدر كربونى لانتاج الفيبرينيز من استربتوميسيس اسبيروفيرتيسيلاتس. • معدن المنجنيز فى صورة كلوريد هو أحسن مصدر معدنى لانتاج الانزيم.

وكذلك امتدت الدراسة لتنقية وفصل انزيم الفيبرينيز و تحديد خواصة وصفاتة من استربتوميسيس فيو لاسيوروبر واستربتوميسيس اسبيروفيرتيسيلاتس. تمت التنقية عن طريق ترسيب الانزيم باستخدام كبريتات الأمونيوم نركيز 70\% , جيل فوسفات الكالسيوم, الديلسة (باستخدام غلاف السلوفان) ثم استخدام تقنية الكروماتوجر افى بواسطة أعمدة السيفادكس جى 100 وقد وجد أن الوزن الجزيئى لانزيم الفيبرينيز هو 30 كيلو دالتون وأن الانزيم يتكون من وحدة واحدة وذلك باستخدام تقنية الالكتروفوريسيس. انزيم الفيبرينيز أبدى نشاط بيولوجى واضح حيث أن له قابليه عالية تجاه الجلطة الدموية من الانسان. 